\title{
固定子鉄損を考慮したリラクタンスモータの モデル化とパラメータ測定法
}

$\begin{array}{llllll}\text { 正員上 } & \text { 里 } & \text { 勝 } & \text { 実 } & \text { (琉球 大) } \\ \text { 正 } & \text { 員 } & \text { 住 } & \text { 智 } & \text { 信 } & \text { (琉球 大) } \\ \text { 正員 友 } & \text { 利 } & \text { 好 } & \text { 克 } & \text { (琉球 大) }\end{array}$

\begin{abstract}
Modeling and Parameter Measurement of Synchronous Reluctance Motors Including Stator Iron Loss

Katsumi Uezato, Member, Tomonobu Senjyu, Member, Yoshikatsu Tomori, Member (University of the Ryukyus)
\end{abstract}

This paper presents voltage equations and a parameter measurement for synchronous reluctance motors including the stator iron loss. The stator iron loss is modelled by additional windings on three-phase axes. These windings are transformed into $d-q$ axes and are represented as equivalent eddy current circuits. The stator iron loss is introduced as equivalent iron loss resistances in voltage equations on the assumption that the losses in the stator core are produced in the equivalent eddy current circuits on $d-q$ axes. The voltage equations including the equivalent iron loss resistances are derived by use of time constant approximations of equivalent eddy current circuits.

Parameters, which are the equivalent iron loss resistance and the $d-q$ axes self-inductances, in the voltage equations are measured by $P-Q$ circle diagram method. As the $P-Q$ circle diagram method is implemented in synchronous condition, the exactly measurement is possible.

キーワード : リラクタンスモータ, 鉄損, $d-q$ 巻線モデル, $P-Q$ 円線図法

\section{1.まえがき}

リラクタンスモータは，同期電動機のように回転子側に 界磁巻線を持たないため，励磁電流を固定子巻線（電源） から供給しなければならず，一次電流が比較的大きく，力 率が小さいという久点がある。しかし，回転子の構造が極 めて簡単で, かつ堅军であるため, 近年高速用電動機とし て注目され, 超高速発電機としての研究も行われてい $3^{(1)}$ 。

これまでのリラクタンスモータの特性検討においては, 主に固定子抢よび回転子巻線の直軸, 横軸インダクタンス と抵抗分のみが考慮されてきた。損失面から見た場合, 固 定子および回転子の銅損のみが考慮され, 固定子鉄損およ び回転子鉄損などの影響は無視されている。しかし, 上述 のような電動機の高速化および精密な速度制御に際して は, 駆動周波数の増加に伴う固定子鉄損の増加が無視でき ないものとなる。これまで, 固定子鉄損を等価的な鉄損抵 抗とおき, 励磁インダクタンスに並列に挿入したモデルに 対して, 固定子鉄損抵抗を含めたパラメータの測定法やべ クトル制御法などが検討されているが(1)(2)，そのモデルに 対する理論的な展開は十分でないように思える。すなわ
ち, 理論的に電圧方程式を導出することなく, 物理的な考 察からこれまでの等価回路に等価鉄損抵抗を挿入している ため, 過渡時の $d-q$ 軸の干渉まで明確にすることができ なかった。

文献 (3)では, 誘導機に関する固定子鉄損抵抗を考慮し た電圧方程式を巻線モデルから理論的に導出し, 過渡時の 等価鉄損抵抗の振る舞いを明らかにしている。しかし, 理 論展開の基礎となる $d-q$ 巻線モデルについては, 固定子 鉄損を表現する等価うず電流回路が単に $d-q$ 軸上（回転 座標）に挿入されており，実際の三相固定子上に発生する 鉄損と $d-q$ 軸上の等価うず電流回路との関係が不明確で あるように思われる。一方, リラクタンスモータは回転子 の突極性のため, 三相巻線のインダクタンスは回転子位置 角の関数となり, 単に等価うず電流回路を $d-q$ 軸上に括 入できるのか問題である。さらに， $d$ 軸枋よび $q$ 軸で磁 束分布が異なるため, 固定子鉄損が $d-q$ 軸上でどのよう に表現されるか不明である。

本論文では，固定子鉄損が固定子内に存在する等価うず 電流回路で生じる(3) という仮定のもとに三相巻線モデル を設定し，固定子鉄損を導入したリラクタンスモータの電 圧方程式を導出する ${ }^{(4)(5)}$ 。固定子鉄損は, 三相巻線軸上で 
同一巻線抵抗および回転子位置角の関数であるインダクタ ンスを有する等価うず電流巻線としてモデル化し, 三相二 相変搮により, $d-q$ 軸上の等価うず電流回路として導入 する。したがって，三相固定子上で発生する鉄損と $d-q$ 軸上の等価うず電流回路との関係が明確になる。このd$q$ 巻線モデルに対して，まず固定子鉄損を考虑した定常状 態の電圧方程式扔よび過渡時の電圧方程式の導出に必要な 近似を導く。次いで，得られた近似式を用いて固定子鉄損 を考慮した過渡時の電圧方程式を導出する(5)。得られた電 圧方程式から，等価鉄損抵抗は $d-q$ 軸で同一となること， また過渡時の鉄損の影響は突極機（リラクタンスモータ） と誘導機で同様になることを示す。また, 導出した近似式 を用いて等価鉄損抵抗が駆動周波数の関数となることを理 論的に示す。

リラクタンスモータや突極形同期機に関する直軸抢よび 横軸りアクタンスの測定法については，これまで各種の方 法が提案されている(6)(7)。また， $P-Q$ 円線図法を用いて 等価鉄損抵抗を含めた固定子諸星の測定法も検討されてい るが(1)，等価鉄損抵抗が励磁インダクタンスに対して並列 に㨉入されるため測定法に関する理論展開が複雑であり， 等価回路定数に関する近似が必要となる。

本論文では，前述した電圧方程式の中に含まれる等価回 路定数が， $P-Q$ 円線図法を用いて決定できることを示す。 さらに，本算定法によって等価回路定数を算定し，その妥 当性を実験により検証する。また，得られた等価回路定数 を用いて, 過渡時の電圧方程式の導出に際して導入した近 似式の妥当性を示す。本論文で提案する測定法は，等価鉄 損抵抗が励磁インダクタンスに対して直列に挿入されるた め，測定法に関する理論展開が容易であり，また等価回路 定数に関する近似を必要としないため, 正確なパラメータ 算定が可能である。

本論文で導出する固定子鉄損抵抗を含む電圧方程式は, リラクタンスモータの過渡的特性を表現できるため, ベク トル制御に適用可能である。ベクトル制御は, 電圧方程式 に基づいて行われるため, 機器定数はあらかじめ測定して おく必要があり，その一测定法として本測定法を提案す る。

\section{2. 鉄損を考慮した電圧方程式}

本章では，まず電圧方程式の導出に際しての仮定を設 け，それに基づいて三相巻線モデルを設定する。次いで， 三相巻線モデルを三相二相変換することにより， $d-q$ 巻 線モデルを導出し，得られた $d-q$ 巻線モデルを基に過渡 状態の電圧方程式を導出して, 過渡時の等価鉄損抵抗の影 響を明確にする。さらに, 本論文で導入した等価鉄損抵抗 が駆動周波数の関数となることを理論的に示す。なお，ダ ンパレスの回転子を対象として理論展開している。

〈2・1〉仮定と巻線モデル 電圧方程式の導出に際し, 以下の三つの仮定を設ける。

（a）電流および磁束の高調波成分は考慮しない。

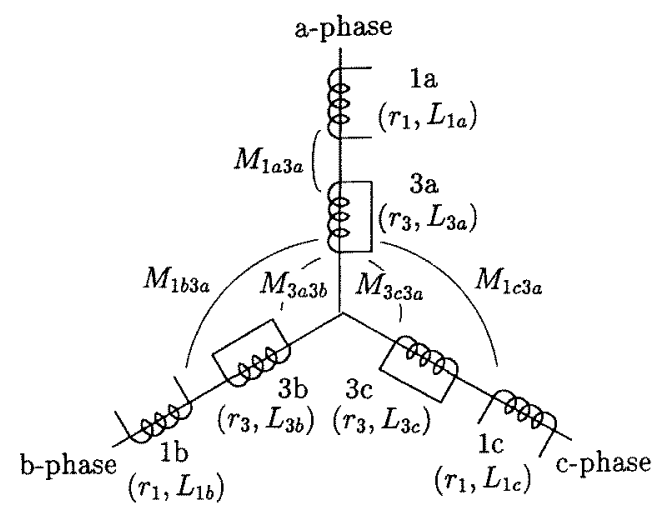

図 1 三相巻線モデル

Fig. 1. Three-pahse winding model.

（b）磁気飽和現象，回転子鉄損および漂遊負荷損は無 視する。

（c）固定子鉄損は固定子内に存在する等価うず電流回 路で生じるものとする。

（c）の仮定は固定子内に分布するうず電流を集中回路と して取り扱うものである。

以上の仮定に従って，三相巻線軸上に，同一巻線抵抗お よび回転子位固角の関数であるインダクタンスを有する等 価うず電流巻線を仮定した，三相巻線モデルを図1のよう に設定する。同図において, $1 a, 1 b, 1 c$ は三相固定子巻 線, $3 a, 3 b, 3 c$ は三相等洒うず電流巻線を表わし, 括弧内 の $r$ および $L$ は各巻線の巻線抵抗および自己インダクタ ンスを表わす。また， $M$ は各巻線間の相互インダクタン スを表わし，各添え字は各巻線を表わす。ここで，図の表 示の煩雑さを避けるため, 相互インダクタンスは $a$ 相の 等価うず電流巻線についてのみ示している。

リラクタンスモータは突極機であるため, 固定子巻線お よび等価うず電流巻線のインダクタンスは, 回転子の位置 角 $\theta_{r}$ により変化し，固定子巻線扔よび等価うず電流巻線 の自己インダクタンスは, 次式のように $2 \theta_{r}$ の関数として 表わすことができる。

$$
\begin{aligned}
L_{1 a 1 a} & =L_{11}+L_{10} \cos 2 \theta_{r} \\
L_{1 b 1 b} & =L_{11}+L_{10} \cos \left(2 \theta_{\tau}+\frac{2}{3} \pi\right) \\
L_{1 c 1 c} & =L_{11}+L_{10} \cos \left(2 \theta_{r}-\frac{2}{3} \pi\right) \\
L_{3 a 3 a} & =L_{33}+L_{30} \cos 2 \theta_{r} \\
L_{3 b 3 b} & =L_{33}+L_{30} \cos \left(2 \theta_{r}+\frac{2}{3} \pi\right) \\
L_{3 c 3 c} & =L_{33}+L_{30} \cos \left(2 \theta_{r}-\frac{2}{3} \pi\right) \\
\text { ただ } & \\
L_{11}= & \frac{\left(L_{1 \max }+L_{1 \min }\right)}{2}, \quad L_{10}=\frac{\left(L_{1 \max }-L_{1 \min }\right)}{2} \\
L_{33}= & =\frac{\left(L_{3 \max }+L_{3 \min }\right)}{2}, \quad L_{30}=\frac{\left(L_{3 \max }-L_{3 \min }\right)}{2}
\end{aligned}
$$


ここで， $L_{1 \max }$ および $L_{3 \max }$ はそれぞれ固定子および等 価うず電流巻線のインダクタンスの最大值を表わし， $L_{1 \mathrm{~min}}$ および $L_{3 \mathrm{mln}}$ はインダクタンスの最小值を表わして いる。

次に，固定子巻線間および等価うず電流巻線間の相互イ ンダクタンスは, 自己インダクタンスと同様に $2 \theta_{r}$ の関数 として次式のように表わされる。

$$
\begin{aligned}
& M_{1 a 1 b}=-\frac{1}{2} L_{11}+L_{10} \cos \left(2 \theta_{r}-\frac{2}{3} \pi\right) \\
& M_{1 b 1 c}=-\frac{1}{2} L_{11}+L_{10} \cos 2 \theta_{r} \\
& M_{1 c 1 a}=-\frac{1}{2} L_{11}+L_{10} \cos \left(2 \theta_{r}+\frac{2}{3} \pi\right) \\
& M_{3 a 3 b}=-\frac{1}{2} L_{33}+L_{30} \cos \left(2 \theta_{r}-\frac{2}{3} \pi\right) \\
& M_{3 b 3 c}=-\frac{1}{2} L_{33}+L_{30} \cos 2 \theta_{r} \\
& M_{3 c 3 a}=-\frac{1}{2} L_{33}+L_{30} \cos \left(2 \theta_{r}+\frac{2}{3} \pi\right)
\end{aligned}
$$

さらに，固定子巻線と等価うず電流巻線間の相互インダ クタンスは, 次式のように表わされる。

$$
\begin{aligned}
& M_{1 a 3 a}=L_{13}+L_{130} \cos 2 \theta_{r} \\
& M_{1 b 3 b}=L_{13}+L_{130} \cos \left(2 \theta_{r}+\frac{2}{3} \pi\right) \\
& M_{1 c 3 c}=L_{13}+L_{130} \cos \left(2 \theta_{r}-\frac{2}{3} \pi\right) \\
& M_{1 a 3 b}=M_{1 b 3 a}=-\frac{1}{2} L_{13}+L_{130} \cos \left(2 \theta_{r}-\frac{2}{3} \pi\right) \\
& M_{1 b 3 c}=M_{1 c 3 b}=-\frac{1}{2} L_{13}+L_{130} \cos 2 \theta_{r} \\
& M_{1 c 3 a}=M_{1 a 3 c}=-\frac{1}{2} L_{13}+L_{130} \cos \left(2 \theta_{r}+\frac{2}{3} \pi\right)
\end{aligned}
$$

ただし，

$$
L_{13}=\frac{\left(L_{13 \max }+L_{13 \min }\right)}{2}, \quad L_{130}=\frac{\left(L_{13 \max }-L_{13 \min }\right)}{2}
$$

ここで， $L_{13 \max }$ および $L_{13 \min }$ は，固定子巻線と等価うず 電流巻線の相互インダクタンスの最大值および最小值を表 わしている。

文献 (2 )では，固定子鉄損を表現する三相巻線は同相の 固定子巻線とのみ磁気結合されており, 他相との磁気関係 は考慮されていない。しかし, 固定子巻線間に相互インダ クタンスが存在するように, 固定子鉄損は同相巻線のみで なく他相巻線の磁束にも影響するので，上述のようにすべ ての巻線との磁気結合を考慮しなければならない。

以上の自己インダクタンスおよび相互インダクタンスを 用いると, 図 1 の三相巻線モデルに対する電圧方程式は次 式のように表わされる。

$$
\left[\boldsymbol{v}_{a b c}\right]=[\boldsymbol{r}]\left[\boldsymbol{i}_{a b c}\right]+p[\boldsymbol{L}]\left[\boldsymbol{i}_{a b c}\right]
$$
ただし，

$\left[\begin{array}{llllll}\boldsymbol{v}_{a b c}\end{array}\right]=\left[\begin{array}{llllll}v_{1 a} & v_{1 b} & v_{1 c} & 0 & 0 & 0\end{array}\right]^{t}$

$\left[\boldsymbol{i}_{a b c}\right]=\left[\begin{array}{llllll}i_{1 a} & i_{1 b} & i_{1 c} & i_{3 a} & i_{3 b} & i_{3 c}\end{array}\right]^{t}$

$[\boldsymbol{r}]=\operatorname{diag}\left[\begin{array}{llllll}r_{1} & r_{1} & r_{1} & r_{3} & r_{3} & r_{3}\end{array}\right]$

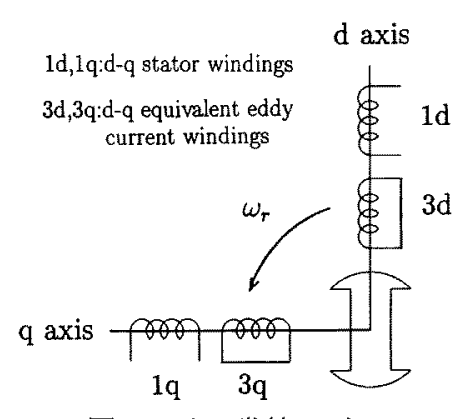

図 $2 d-q$ 巻線モデル

Fig. 2. $d-q$ winding model.

$[\boldsymbol{L}]=\left[\begin{array}{llllll}L_{1 a 1 a} & M_{1 a 1 b} & M_{1 c 1 a} & M_{1 a 3 a} & M_{1 a 3 b} & M_{1 a 3 c} \\ M_{1 a 1 b} & L_{1 b 1 b} & M_{1 b 1 c} & M_{1 b 3 a} & M_{1 b 3 b} & M_{1 b 3 c} \\ M_{1 c 1 a} & M_{1 b 1 c} & L_{1 c 1 c} & M_{1 c 3 a} & M_{1 c 3 b} & M_{1 c 3 c} \\ M_{1 a 3 a} & M_{1 b 3 a} & M_{1 c 3 a} & L_{3 a 3 a} & M_{3 a 3 b} & M_{3 c 3 a} \\ M_{1 a 3 b} & M_{1 b 3 b} & M_{1 c 3 b} & M_{3 a 3 b} & L_{3 b 3 b} & M_{3 b 3 c} \\ M_{1 a 3 c} & M_{1 b 3 c} & M_{1 c 3 c} & M_{3 c 3 a} & M_{3 b 3 c} & L_{3 c 3 c}\end{array}\right]$

(1) 式の電圧方程式を回転子角速度 $\omega_{r}$ で回転する $d-q$ 軸上へ三相二相変換すると, 図 $20 d-q$ 巻線モデルが得 られる。同図において, $1 d, 1 q$ は固定子 $d-q$ 巻線, 3 $d, 3 q$ は等価うず電流回路の $d-q$ 巻線を表わす。図 2 は, 文献 (3)で導入された $d-q$ 巻線モデルとほぼ同一で あるが，回転子の突極性を考慮しているため各巻線のイン ダクタンスが $d-q$ 軸で異なる。また突極機においては, 三相軸上の等価うず電流巻線に関して他のすべての巻線と の磁気結合を考慮しなければ, 図 2 の $d-q$ 巻線モデルは 得られない。

以下，この巻線モデルに対する電圧方程式を導出する。

図 2 の巻線モデルに対する電圧方程式および磁束鎖交数 は，次式のようになる。

$$
\left[\begin{array}{l}
v_{1 d} \\
v_{1 q} \\
0 \\
0
\end{array}\right]=\left[\begin{array}{cccc}
r_{1}+p L_{1 d}^{\prime} & -\omega_{r} L_{1 q}^{\prime} & p M_{d}^{\prime} & -\omega_{r} M_{q}^{\prime} \\
\omega_{r} L_{1 d}^{\prime} & r_{1}+p L_{1 q}^{\prime} & \omega_{r} M_{d}^{\prime} & p M_{q}^{\prime} \\
p M_{d}^{\prime} & -\omega_{r} M_{q}^{\prime} & r_{3}+p L_{3 d} & -\omega_{r} L_{3 q} \\
\omega_{r} M_{d}^{\prime} & p M_{q}^{\prime} & \omega_{r} L_{3 d} & r_{3}+p L_{3 q}
\end{array}\right]\left[\begin{array}{c}
i_{1 d} \\
i_{1 q} \\
i_{3 d} \\
i_{3 q}
\end{array}\right]
$$

$$
\left.\begin{array}{ll}
\Psi_{1 d}=L_{1 d}^{\prime} i_{1 d}+M_{d}^{\prime} i_{3 d}, & \Psi_{\mathrm{lq}}=L_{1 q}^{\prime} i_{1 q}+M_{q}^{\prime} i_{3 q} \\
\Psi_{3 d}=L_{3 d} i_{3 d}+M_{d}^{\prime} i_{1 d}, & \Psi_{3 q}=L_{3 q} i_{3 q}+M_{q}^{\prime} i_{1 q}
\end{array}\right\}
$$
ただし，

$$
\begin{array}{ll}
L_{1 d}^{\prime}=\frac{3}{2}\left(L_{11}+L_{10}\right), & L_{1 q}^{\prime}=\frac{3}{2}\left(L_{11}-L_{10}\right) \\
L_{3 d}=\frac{3}{2}\left(L_{33}+L_{30}\right), & L_{3 q}=\frac{3}{2}\left(L_{33}-L_{30}\right) \\
M_{d}^{\prime}=\frac{3}{2}\left(L_{13}+L_{130}\right), & M_{q}^{\prime}=\frac{3}{2}\left(L_{13}-L_{130}\right)
\end{array}
$$

ここで, $v$ :入力電圧, $i:$ 電流， $\Psi$ : 磁束鎖交

数, $r$ : 各巻線抵抗, $L:$ 各巻線の当己インダク タンス, $M$ : 各巻線間の相互インダクタンス, $p$ : 微分演算子, $\omega_{r}$ : 回転子角速度, 各添え字は 各巻線を表わす

(2) 式は等価うず電流を含んだ電圧方程式である。一般 
に，等価うず電流の検出は困難であり，そのため等価うず 電流回路定数の測定も困難となる。したがって, 本論文で は, 固定子側諸量のみで表現される電圧方程式を導出する ため，(2)式から等価うず電流を消去する。しかし，（2） 式の 3,4 行目加ら $i_{3 d}, i_{3 q}$ を求め, 直接 1,2 行目の $i_{3 d}, i_{3 q}$ を消去すると $p^{3}$ を含む複雑な式となる。したがって等価 回路定数の近似式を用いて過渡状態の電圧方程式を導出す るために，まず定常状態の電圧方程式を導出する。

〈2・2〉定常状態の電圧方程式と近似式（2)式の 3,4 行目を， $i_{3 d}, i_{3 q}$ について解くと次式のようになる。 $i_{3 d}=-D_{r}\left\{\left(p r_{3}+\omega_{r}^{2} L_{3 q}\right) M_{d}^{\prime} i_{1 d}-\left(r_{3}-p L_{3 q}\right) \omega_{r} M_{q}^{\prime} i_{1 q}\right\}$

$i_{3 q}=-D_{r}\left\{\left(p r_{3}+\omega_{r}^{2} L_{3 d}\right) M_{q}^{\prime} i_{1 q}+\left(r_{3}-p L_{3 d}\right) \omega_{r} M_{d}^{\prime} i_{1 d}\right\}$

ただし，

$$
D_{r}=1 /\left(r_{3}^{2}+\omega_{r}^{2} L_{3 d} L_{3 q}\right)
$$

(2) 式は回転子角速度 $\omega_{r}$ で回転する回転座標上の電圧 方程式であるため, 定常状態に扔ける各電流は直流量とな り，微分演算子 $p$ は零と扔ける。したがって，(2)，

(4)，（5)式中の微纷演算子 $p$ を零と扔くと,

$$
\left.\begin{array}{l}
v_{1 d}=r_{1} i_{1 d}-\omega_{r} L_{1 q}^{\prime} i_{1 q}-\omega_{r} M_{q}^{\prime} i_{3 q} \\
v_{1 q}=r_{1} i_{1 q}+\omega_{r} L_{1 d}^{\prime} i_{1 d}+\omega_{r} M_{d}^{\prime} i_{3 d}
\end{array}\right\} \quad \ldots .
$$

となる。（7)式を(6)式に代入することにより，等価うず 電流回路定数を含む, 新しい等価回路定数で表現された定 常状態の電圧方程式が次式のように得られる。

$$
\left[\begin{array}{l}
v_{1 d} \\
v_{1 q}
\end{array}\right]=\left[\begin{array}{cc}
r_{1}+r_{m} & -\omega_{r} L_{q} \\
\omega_{r} L_{d} & r_{1}+r_{m}
\end{array}\right]\left[\begin{array}{l}
i_{1 d} \\
i_{1 q}
\end{array}\right]
$$

ただし，

$$
\left.\begin{array}{l}
L_{d}=L_{1 d}^{\prime}-D_{r} \omega_{r}^{2} M_{d}^{\prime 2} L_{3 q} \\
L_{q}=L_{1 q}^{\prime}-D_{r} \omega_{r}^{2} M_{q}^{\prime 2} L_{3 d} \\
r_{m}=D_{r} \omega_{r}^{2} M_{d}^{\prime} M_{q}^{\prime} r_{3}
\end{array}\right\}
$$

ここで, $L_{d}, L_{q}:$ 固定子 $d$ 軸および $q$ 軸自己イ ンダクタンス, $r_{1}$ : 固定子巻線抵抗, $r_{m}$ : 等価鉄 損抵抗

(8) 式から等価鉄損抵抗 $r_{m}$ は, 励磁インダクタンスに 対して直列に挿入され， $d-q$ 軸で同一となることがわか る。したがって, 励磁電流と端子電流は同一となり, 電機 子端子から直接励磁電流を検出することが可能となるた め，等価鉄損抵抗が励磁インダクタンスに対し並列に㨂入 されるモデル(2)に比べ，バクトル制御の適用が容易にな ると考えられる。

次に，過渡状態の電圧方程式を導出する際に必要となる 近似式を導く。リラクタンスモー夕は突極機であり $d-q$ 軸のインダタタンスが異なるため, 文献 (3)の近似式を直 接適用できない。したがって， $d$ 軸および $q$ 軸に関する 近似式を( 9 )式の等価回路定数 $L_{d}, L_{q}$ および $r_{m}$ より導 出する。

固定子の鉄損またはうず電流は，固定子巻線で発生した
磁束によって生じるため, 等価うず電流回路の漏れ磁束は ほほ零と考えられる。したがって等価うず電流回路の漏れ インダクタンスはほほ零となる。また固定子巻線の漏れイ ンダクタンスが, 固定子自己インダクタンスに比較して十 分小さいと仮定すると, 次の関係式が成立する。

$$
\begin{aligned}
& L_{1 d}^{\prime} \simeq M_{d}^{\prime} \simeq L_{3 d} \\
& L_{1 q}^{\prime} \simeq M_{q}^{\prime} \simeq L_{3 q}
\end{aligned}
$$

これらの関係式を用いると，(9)式の等価回路定数 $r_{m}$, $L_{a}$ および $L_{q}$ は次式のように表わすことができる。

$$
\left.\begin{array}{l}
r_{m} \simeq D_{r} \omega_{r}^{2} L_{3 d} L_{3 q} r_{3} \\
L_{d} \simeq D_{r} r_{3}^{2} L_{3 d} \\
L_{q} \simeq D_{r} r_{3}^{2} L_{3 q}
\end{array}\right\}
$$

(10) 式加ら

$$
\left.\begin{array}{l}
r_{m} / L_{d} \simeq \omega_{r}^{2} L_{3 q} / r_{3} \\
r_{m} / L_{q} \simeq \omega_{r}^{2} L_{3 d} / r_{3}
\end{array}\right\}
$$

したがって，(11)式から次の関係が成立する。

$$
\left.\begin{array}{l}
L_{3 d} / r_{3} \simeq r_{m} /\left(\omega_{r}^{2} L_{q}\right) \ll 1 \\
L_{3 q} / r_{3} \simeq r_{m} /\left(\omega_{r}^{2} L_{d}\right) \ll 1
\end{array}\right\}
$$

(12)式は，等価うず電流回路の時定数が 1 よりも十分小さ いことを示している。さらに，(11)式から次の関係も成立 する。

$$
\left.\begin{array}{l}
r_{3} /\left(\omega_{r}^{2} L_{3 d}\right) \simeq L_{q} / r_{m} \ll 1 \\
r_{3} /\left(\omega_{r}^{2} L_{3 q}\right) \simeq L_{d} / r_{m} \ll 1
\end{array}\right\}
$$

(12)式および(13)式の関係は, 次章の実験で測定される 等価回路定数によりその妥当性が示される。

一般に，等価鉄損抵抗は駆動周波数の増加に伴って増加 する。本論文で導入した等価鉄損抵抗も駆動周波数の関数 となることを(12)式を用いて示す。

等価鉄損抵抗 $r_{m}$ は, $(9)$ 式より

$$
\begin{aligned}
r_{m} & =D_{r} \omega_{r}^{2} M_{d}^{\prime} M_{q}^{\prime} r_{3} \\
& =\frac{\omega_{r}^{2} M_{d}^{\prime} M_{q}^{\prime} r_{3}}{r_{3}^{2}+\omega_{r}^{2} L_{3 d} L_{3 q}} \\
& =\frac{\omega_{r}^{2} M_{d}^{\prime} M_{q}^{\prime} r_{3}}{r_{3}^{2}\left\{1+\left(\omega_{r} L_{3 d} / r_{3}\right)\left(\omega_{r} L_{3 q} / r_{3}\right)\right\}}
\end{aligned}
$$

と表わされる。ここで, 等価うず電流回路の時定数の関係 式(12)式から,

$$
\left.\begin{array}{l}
\omega_{r} L_{3 d} / r_{3} \simeq r_{m} /\left(\omega_{r} L_{1 q}\right) \\
\omega_{r} L_{3 q} / r_{3} \simeq r_{m} /\left(\omega_{r} L_{1 d}\right)
\end{array}\right\}
$$

となり, 次の関係式が成立する。

$\left(\omega_{r} L_{3 d} / r_{3}\right)\left(\omega_{r} L_{3 q} / r_{3}\right) \simeq r_{m}^{2} /\left(\omega_{r} L_{1 q} \omega_{r} L_{1 d}\right) \ll 1$

(16)式の妥当性は, 次章の実験で測定される等価回路定数 から容易に確認できる。したがって，(14)式は，

$$
\begin{aligned}
r_{m} & \simeq \frac{\omega_{r}^{2} M_{d}^{\prime} M_{q}^{\prime} r_{3}}{r_{3}^{2}} \\
& =\omega_{r}^{2} \frac{M_{d}^{\prime} M_{q}^{\prime}}{r_{3}} \\
& =\omega_{r}^{2} K_{m} \ldots \ldots . .
\end{aligned}
$$

ただし， $K_{m}=\frac{M_{d}^{\prime} M_{q}^{\prime}}{r_{3}}$

となる。（17)式は，等価鉄損抵抗 $r_{m}$ が回転子角速度 $\omega_{r}$ の 2 乗にほほ比例することを示している。リラクタンスモ 
一夕は同期電動機であり, 回転子角速度 $\omega_{r}$ と電源の駆動 角周波数とは同一となることから， $r_{m}$ は駆動周波数の関 数として変化し, 通常の巻線抵抗とは異なったものとな る。

次節では，(12)式および(13)式で表わされる近似式を用 いて過渡状態の電圧方程式を尊出する。

〈2・3〉過渡状態の電圧方程式 等価うず電流に関す る(4)式および(5)式は, 次式のように変形できる。

$$
\begin{aligned}
i_{3 d}=-D_{r}[ & \left(p \frac{r_{3}}{\omega_{r}^{2} L_{3 q}}+1\right) \omega_{r}^{2} L_{3 q} M_{d}^{\prime} i_{1 d} \\
& \left.-\left(1-p \frac{L_{3 q}}{r_{3}}\right) r_{3} \omega_{r} M_{q}^{\prime} i_{1 q}\right] \\
i_{3 q}=-D_{r}[ & \left(p \frac{r_{3}}{\omega_{r}^{2} L_{3 d}}+1\right) \omega_{r}^{2} L_{3 d} M_{q}^{\prime} i_{1 q} \\
& \left.+\left(1-p \frac{L_{3 d}}{r_{3}}\right) r_{3} \omega_{r} M_{d}^{\prime} i_{1 d}\right]
\end{aligned}
$$

(12)式扔よび(13)式の関係を用いて，(18)式㧍よび(19) 式を近似すると次式のようになる。

$$
\begin{aligned}
& i_{3 d} \simeq-D_{r}\left(\omega_{\tau}^{2} L_{3 q} M_{d}^{\prime} i_{1 d}-r_{3} \omega_{r} M_{q}^{\prime} i_{1 q}\right) \\
& i_{3 q} \simeq-D_{r}\left(\omega_{r}^{2} L_{3 d} M_{q}^{\prime} i_{1 q}+r_{3} \omega_{r} M_{d}^{\prime} i_{1 d}\right)
\end{aligned}
$$

したがって(20)式抒よび(21)式を(2)式に代入して， $i_{3 d}, i_{3 q}$ を消去すると, 固定子鉄損を考慮した過渡状態の電 圧方程式が次式のように得られる。

$$
\begin{aligned}
& {\left[\begin{array}{c}
v_{1 d} \\
v_{1 q}
\end{array}\right]=\left[\begin{array}{ll}
r_{1}+r_{m}+p L_{d} & -\omega_{r} L_{q}+p K_{r m} \\
\omega_{r} L_{d}-p K_{r m} & r_{1}+r_{m}+p L_{q}
\end{array}\right]\left[\begin{array}{c}
i_{1 d} \\
i_{1 q}
\end{array}\right] } \\
& \text { ここで, } K_{r m}=r_{m} / \omega_{r}
\end{aligned}
$$

さらに，(20)式および(21)式を(3) 式に代入すると，d 軸抢よび $q$ 軸磁束鎖交数は次式のようになる。

$$
\left.\begin{array}{l}
\Psi_{1 d}=L_{d} \dot{i}_{1 d}+K_{r m} i_{1 q} \\
\Psi_{1 q}=L_{q} i_{1 q}-K_{m m} i_{1 d}
\end{array}\right\}
$$

したがって, 電磁トルクの瞬時值は次式で与えられる。

$$
\begin{aligned}
& \tau_{e}=(3 / 2) P\left(\Psi_{1 d} i_{1 q}-\Psi_{1 q} i_{1 d}\right) \\
&=(3 / 2) P\left\{\left(L_{d}-L_{q}\right) i_{1 d} i_{1 q}+K_{r m}\left(i_{1 d}^{2}+i_{1 q}^{2}\right)\right\} \\
& \text { ここで, } P: \text { 極効数 }
\end{aligned}
$$

(22)式に扔いて，Krm が $r_{m}$ を含むことから， $d-q$ 軸が 等価鉄損抵抗を介して互いに干涉し, 一種の変圧器起電力 として現われることがわかる。また(23)式から, 固定子磁 束鎖交数が等価鉄損抵抗 介して互いに干渉することがわ かる。つまり, $d$ 軸磁束鎖交数は $d$ 軸電流だけでなく, 等価鉄損抵抗を介して $q$ 軸電流にも影響され， $q$ 軸磁束鎖 交数もまた同様に $d$ 軸および $q$ 軸電流に影響される。こ の磁束鎖交数の干渉のため，電磁トルクが等価鉄損抵抗の 影響を受けることになる。したがって, ベクトル制御を適 用するためには， $d$ 軸および $q$ 軸磁束の非干涉化が必要 である。

なお (22)式は, 固定子鉄損を考慮したリラクタンスモー 夕の過渡的ふるまいを表現しているため, 瞬時トルクを制 御するベクトル制御に適用可能である。ベクトル制御は電 圧方程式に基づいて行われるため，その中に含まれる等価 回路定数はあらかじめ測定しておく必要がある。そこで, 次章では等価回路定数の測定法について示す。

\section{3. パラメータ測定法}

等価回路定数の測定には，P-Q 円線図法を用いる。 $P-$ $Q$ 円線図法は，リラクタンスモータを同期速度で運転し， 徐々に負荷をかけたときの有効電力および無効電力を測定 して, 縌軸に有効電力, 横軸に無効電力をとった $P-Q$ 円 線図を描き，その中心と半径から，等価鉄損抵抗と直軸お よび横軸同期りアクタンスを決定するものである(1)。

文献(1)では，固定子鉄損を表わす鉄損コンダクタンス が, 励磁インダクタンスに対して並列に捙入されているの で,リラクタンス発電機の出力を導出する際に等価回路定 数に関する近似が必要である。本論文では, 等価鉄損抵抗 が励磁インダクタンスに対して直列に挿入されるため, 近 似を必要とせずにパラメータ算定の理論展開が可能であ る。

〈3・1〉 P-Q 円線図法林クタンスモータが定常 状態であるとき，（2）式中の微分演算子 $p$ は零とおけ, 定常状態の電圧方程式 (8) 式が得られる。このとき, 回転 座標軸上の固定子電流および電圧は直流量になり, 回転子 角速度 $\omega_{r}$ は電源角周波数 $\omega_{e}$ と一致するため, 次の電圧 方程式が得られる。

$$
\left[\begin{array}{c}
V_{1 d} \\
V_{1 q}
\end{array}\right]=\left[\begin{array}{cc}
r_{1}+r_{m} & -\omega_{e} L_{q} \\
\omega_{e} L_{d} & r_{1}+r_{m}
\end{array}\right]\left[\begin{array}{c}
I_{1 d} \\
I_{1 q}
\end{array}\right]
$$

(25)式において， $V_{1 d}, V_{1 q}, I_{1 d}$ および $I_{1 q}$ は実効值であ り, 静止座標軸上では正弦波交流となる。(25)式に対する フェーザ図を図 3 に示す。ただし，

$$
r_{1 m}=r_{1}+r_{m}, \dot{E}_{d}=j \omega_{e} L_{d} \dot{I}_{1 d}, \dot{E}_{q}=j \omega_{e} L_{q} \dot{I}_{1 q}
$$

ところで, 入力端子からみた有効電力 $P$, 無効電力 $Q$ は，相電圧を $V$, 線電流を $I$, 力率を $\phi$ とすると，

$$
\begin{aligned}
& P=V I \cos \phi . \\
& Q=V I \sin \phi .
\end{aligned}
$$

と表わされる。

ここで, 図 3 のフェーザ図から $I \cos \phi, I \sin \phi$ を求め ると,

$I \cos \phi=-I_{1 d} \sin \delta+I_{1 q} \cos \delta$

$I \sin \phi=I_{1 d} \cos \delta+I_{1 q} \sin \delta$

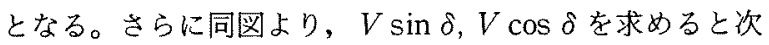
式を得る。

$V \sin \delta=X_{q} I_{1 q}-r_{1 m} I_{1 d}$
$V \cos \delta=r_{1 m} L_{1 q}+X_{d} I_{1 d}$

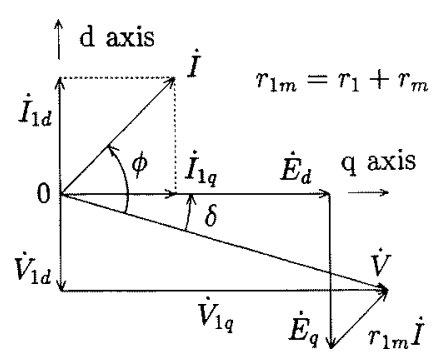

図 3 フェーザ図

Fig. 3. Phaser diagram. 
ここで， $X_{d}=\omega_{e} L_{d}, X_{q}=\omega_{e} L_{q}$ であり，直軸および横軸 同期リアクタンスを表わす。

(30)式打よび(31)式から $I_{1 d}, I_{i q}$ を求め，(28)，(29)式

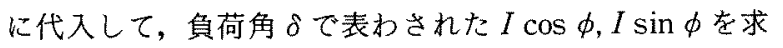
めると次式となる。

$$
\begin{aligned}
& I \cos \phi=\frac{V}{r_{1 m}^{2}+X_{d} X_{q}} r_{1 m}+\frac{X_{d}-X_{q}}{2} \sin 2 \delta \cdots \cdots(32) \\
& I \sin \phi=\frac{V}{r_{1 m}^{2}+X_{d} X_{q}} \frac{X_{d}+X_{q}}{2}-\frac{X_{d}-X_{q}}{2} \cos 2 \delta
\end{aligned}
$$

したがって，(32)，(33)式を(26)，(27)式に代入して有効 電力 $P$, 無効電力 $Q$ を負荷角 $\delta$ を用いて表わすと次式を得る。

$$
\begin{aligned}
& P=P_{0}+A \sin (2 \delta) \\
& Q=Q_{0}-A \cos (2 \delta)
\end{aligned}
$$
ただし，

$$
\begin{aligned}
& P_{0}=\frac{r_{1 m}}{\left(r_{1 m}^{2}+X_{d} X_{q}\right)} V^{2} \\
& Q_{0}=\frac{\left(X_{d}+X_{q}\right)}{2\left(r_{1 m}^{2}+X_{d} X_{q}\right)} V^{2} \\
& A=\frac{\left(X_{d}-X_{q}\right)}{2\left(r_{1 m}^{2}+X_{d} X_{q}\right)} V^{2}
\end{aligned}
$$

(34)式抢よび(35)式において $P_{0}, Q_{0}$ を左辺に移項し両 辺を 2 乗して, 辺々を加えると，

$$
\left(P-P_{0}\right)^{2}+\left(Q-Q_{0}\right)^{2}=A^{2}
$$

となり, 中心 $\left(P_{0}, Q_{0}\right)$, 半径 $A$ の円の方程式が得られる。

電源角周波数 $\omega_{e}$ と入力電圧 $V$ が一定であれば， $X_{d}$, $X_{q}, r_{m}$ は一定となるため, $P_{0}, Q_{0}, A$ は一定值になる。し たがって, 負荷条件つまり負荷角 $\delta$ を変えて有効電力 $P$, 無効電力 $Q$ を複数個測定し, それらの点を通る円を描く ことにより，中心 $\left(P_{0}, Q_{0}\right)$, 半径 $A$ を求めることができ る。円の中心と半径が求まると, 以下の手順により $r_{m}$, $X_{d}, X_{q}$ が算定される。

まず，(36)〜(38)式より $X_{d}, X_{q}$ を求めると，

$$
\begin{aligned}
& X_{d}=\frac{Q_{0}+A}{P_{0}} r_{1 m} \\
& X_{q}=\frac{Q_{0}-A}{P_{0}} r_{1 m}
\end{aligned}
$$

となる。さらに（40)式扔よび(41)式を(36)式に代入して $X_{d}, X_{q}$ を消去し， $r_{m}$ を求めると次式となる。

$$
r_{m}=\frac{P_{0} V^{2}}{P_{0}^{2}+\left(Q_{0}+A\right)\left(Q_{0}-A\right)}-r_{1}
$$

(42)式を(40)式および(41)式に代入すると， $X_{d}, X_{q}$ が 次式のように求まる。

$$
\begin{aligned}
& X_{d}=\frac{Q_{0}+A}{P_{0}} \cdot \frac{P_{0} V^{2}}{P_{0}^{2}+\left(Q_{0}+A\right)\left(Q_{0}-A\right)} \\
& X_{q}=\frac{Q_{0}-A}{P_{0}} \cdot \frac{P_{0} V^{2}}{P_{0}^{2}+\left(Q_{0}+A\right)\left(Q_{0}-A\right)}
\end{aligned}
$$

以上の理論展開において, 等価回路定数 $r_{1}, r_{m}, X_{d}, X_{q}$ に関する近似は行っていないため, 正確なパラメータの算 定が可能である。

〈3.2〉定数算定結果と検討供試電動機には, 定格 $0.2 \mathrm{~kW}, 200 \mathrm{~V}, 4$ 極かご形誘導機の固定子を使用し，回 転子はかご形回転子の一部を削り，突極部を設けたものを
用いる。この実験システムを図 4 に示す。リラクタンスモ 一夕の軸には, 負荷または動力源となる直流機と, 負荷角を 測定するためのロータリエンコーダが直結され，電源は 商用周波数 $60 \mathrm{~Hz}$ で行った。リラクタンスモータを同期速 度で運転し，電動機領域および発電機領域で動作させて, 各々の負荷に対する有効電力および無効電力を測定する(4)。

図 5 は, 測定された有効電力および無効電力を用いて描 いた $P-Q$ 円線図である。网線図より, 中心 $\left(P_{0}, Q_{0}\right)$, 半 径 $A$ は, 以下のように求められる。

$$
\left(P_{0}, Q_{0}\right)=(62.4,207.5), A=81.0
$$

したがって，等価回路定数は以下のように決まる。

$$
r_{m}=9.54(\Omega), X_{d}=103.07(\Omega), X_{q}=45.19(\Omega)
$$

ここで電機子抵抗は, 電圧降下法により求められ， $r_{1}=$ $12.75(\Omega)$ である。

測定結果から，等価鉄損抵抗が $r_{m}=9.54(\Omega)(60 \mathrm{~Hz}$ 駆 動時) と高い值を示していることがわかる。本論文の等価 鉄損抵抗 $r_{m}$ は駆動周波数の増加に伴い増加するため, 供 試機器を高速運転する場合, 周波数の増加に伴う鉄損抵抗 の影響はかなり大きくなるものと思われる。

本測定結果の妥当性を検証するため有効電力対負荷角特 性を図 6 に示す。同図に扔いて, 実線が理論值であり○が 実験值である。理論值と奏測值はほぼ一致しているため, 本测定法は妥当であるといえる。

ここで，過渡時の電圧方程式の導出に際して導入した (12)式扔よび(13) 式の妥当性を, 算定された等価回路定数 を用いて検証して扔く。

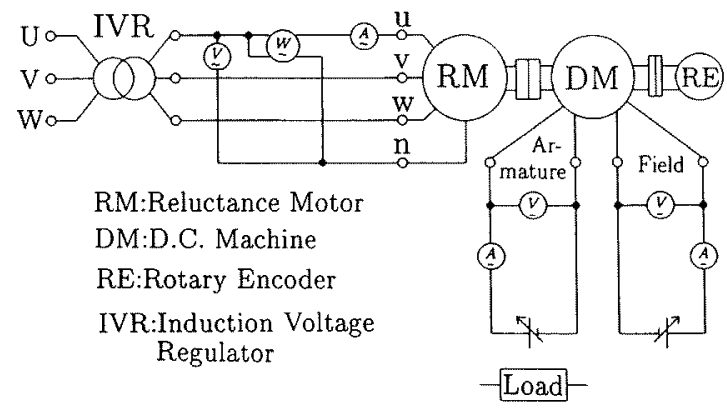

図 4 実験システム

Fig. 4. Experiment system.

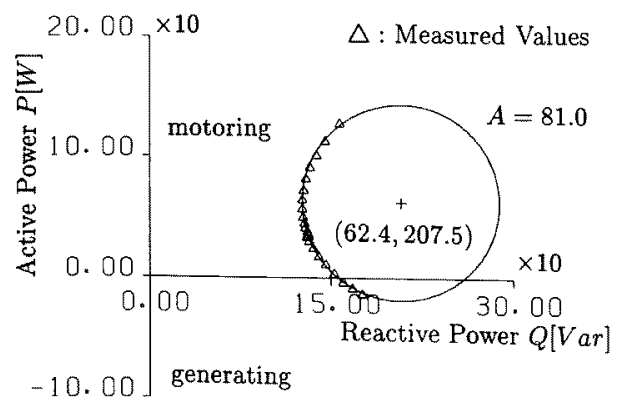

図 $5 \quad P-Q$ 円線図

Fig. 5. $P-Q$ circle diagram. 


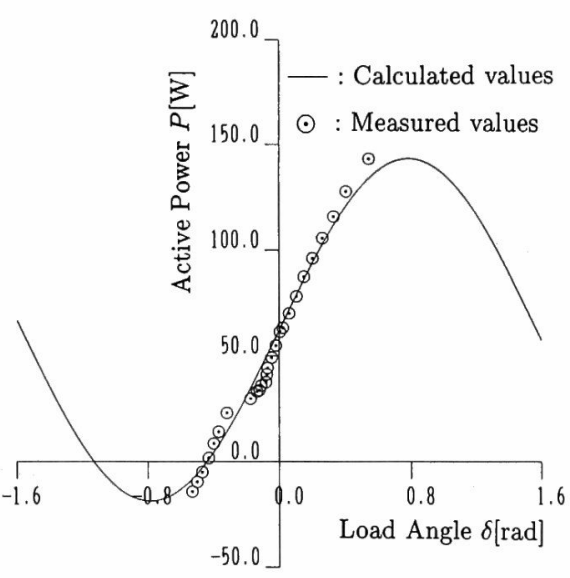

図 6 有効電力対負荷角特性

Fig. 6. Active power versus load angle.

算定結果から, 直軸および横軸インダクタンスは,

$$
L_{d}=X_{d} / \omega_{e}=103.07 /(2 \times \pi \times 60)=0.2734(\mathrm{H})
$$$$
L_{q}=X_{q} / \omega_{e}=45.19 /(2 \times \pi \times 60)=0.1199(\mathrm{H})
$$

となる。したがって, 等価うず電流回路の時定数を表わす (12) 式に, 算定された等価回路定数 $r_{m}, L_{d}$ および $L_{q}$ を 代入すると，

$$
\begin{aligned}
L_{3 d} / r_{3} & \simeq r_{m} /\left(\omega_{r}^{2} L_{q}\right) \\
& =9.54 /\left(377^{2} \times 0.1199\right) \simeq 0.00056 \ll 1 \\
L_{3 q} / r_{3} & \simeq r_{m} /\left(\omega_{r}^{2} L_{d}\right) \\
& =9.54 /\left(377^{2} \times 0.2734\right) \simeq 0.00025 \ll 1
\end{aligned}
$$

となる。同様にして, 算定された等価回路定数を(13)式に 代入すると，

$$
\begin{aligned}
r_{3} /\left(\omega_{r}^{2} L_{3 d}\right) & \simeq L_{q} / r_{m} \\
& =0.1199 / 9.54 \simeq 0.012 \ll 1 \\
r_{3} /\left(\omega_{r}^{2} L_{3 q}\right) & \simeq L_{d} / r_{m} \\
& =0.2734 / 9.54 \simeq 0.029 \ll 1
\end{aligned}
$$

となり，(12)式および(13)式が成立する。

\section{4. むすび}

これまで，固定子鉄損を考慮したリラクタンスモータの パラメー夕測定法およびベクトル制御法に関する研究は, 物理的な考察により導出されたモデルに対して行われ，そ の過渡的なモデル（固定子鉄損のモデル化）に対する理論 的な検討が不十分であった。

本論文では，まず固定子鉄損が固定子内の等価うず電流 回路で生じるという仮定のもとに，三相巻線モデルを設定 し，固定子鉄損を導入したリラクタンスモータの電圧方程 式を理論的に導出した。その結果，リラクタンスモータに おいても誘導電動機の場合(3) と同様に，等価鉄損抵抗は 励磁インダクタンスに対して直列であること，また等価鉄 損抵抗を介して $d$ 軸と $q$ 軸が過渡的に干渉することを示 した。さらに，等価鉄損抵抗は駆動周波数の関数となるこ とを理論的に示し，また磁束分布の異なる $d-q$ 軸の等価 鉄損抵抗が同一となることを明らかにした。

さらに, 導出された電圧方程式をもとに, $P-Q$ 円線図
法を用いて等価回路定数の決定法を提案し，その妥当性を 実験により検証した。算定結果から，等価鉄損抵抗の影響 は大きいことがわかり，高速運転時にはこの影響を考慮す る必要があることを示した。

本論文では，誘導機を対象とした文献（３）とほほ同様な 方法により，固定子鉄損抵抗を導入したが，突極性を有す る機器に対する固定子鉄損抵抗のモデル化を，三相巻線モ デルから理論的に行ったことに有用性がある。またパラメ 一タの測定法は，等価鉄損抵抗が励磁インダクタンスに対 して直列に插入されるため，その理論展開が容易であり， 等価回路定数に関する近似を必要としないので, 正確なパ ラメータ算定が可能である。

(平成 5 年 6 月 24 日受付, 同 6 年 3 月 9 日再受付)

$$
\text { 文献 }
$$

（1）楊・深尾：「鉄損を考慮した超高速リラクタンス発電機の等価回 路と定常特性の考察」, 電学論 D, 110,746 (平 2-6)

(2) L. Xu, X. Xu, T. A. Lipo, et al.: "Vector Control of a Synchronous Reluctance Motor Including Saturation and Iron Loss", IEEE Trans. Industr. Applic., 27, No. 5, 977 (1991)

（3）水野, 他：「固定子鉄損を考虑した誘導電動機の非干涉制御 法」, 電学論 D, 109,841 (平元-11)

（4）上里，他：「鉄損を考慮したリラクタンスモータのパラメータ 測定法」, 電気学会回転機研資, RM-92-158 (平 4)

( 5 ) K. Uezato, et al.: "Parameter Measurement of Synchronous Reluctance Motor Including Stator and Rotor Iron Loss.", Proc. of SMIC '93, 247 (1993)

（6）杉浦・秋山：「直軸および横軸同期リアクタンス $X_{d}, X_{q}$ の各種 測定法」, 電気学会回転機研資, RM-91-125 (平 3)

（7）「同期機試験法要網」, 電気学会技術報告, 第 18 号 (昭 47)

上里勝実 (正員) 1940 年 2 月 5 日生。 1972 年 3 月鹿児島

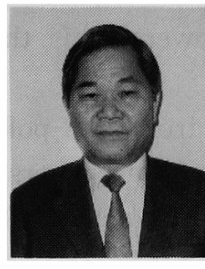
大学大学院工学研究科電気工学専攻修士課程修 了。同年 5 月琉球大学理工学部電気工学科助手, 助教授を経て, 1986 年 5 月同大学工学部教授, 現在に至る。工学博士。主として電気機器の過 渡安定性および制御の研究, 自然エネルギーの 有効利用に関する調査・研究に従事。計測自動制 御学会会員。

千 住 智 信 (正員) 1963 年 5 月 2 日生。1 988 年 3 月琉球大

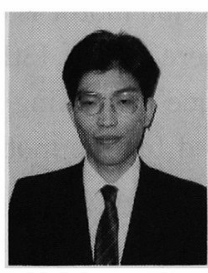
学大学院工学研究科修士課程電気・情報工学専攻 修了。同年 4 月琉球大学工学部電気工学科助手, 現在に至る。博士(工学)。同期機の安定性なら びに制御に関する研究，アドバンスト制御を導 入した電動機とパワーエレクトロニクス機器の 制御ならびに自然エネルギーの開発に従事。計 測自動制御学会, IEEE 会員。

友利 好克（正員）1966 年11月 8 日生。1992 年 3 月琉球

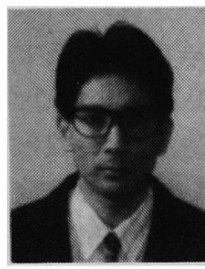
大学工学部電気工学科卒業。1994 年 3 月琉球大 学大学院工学研究科修士課程電気・情報工学専攻 修了。同年 4 月中部電力(株) 入社, 現在に至る。 在学中は, 鉄損を考慮したりラクタンスモータ のモデル化ならびにベクトル制御に関する研究 に従事。 